\title{
PERLINDUNGAN HUKUM PARA PEMEGANG SAHAM DALAM PROSES PERMOHONAN PEMBUBARAN PERSEROAN TERBATAS KEPADA PENGADILAN: Studi Putusan Nomor: $534 \mathrm{~K} /$ $\mathrm{Pdt} / 2014$
}

\author{
Puspita Ika Hapsari, Sihabudin, Budi Santoso \\ Fakultas Hukum Universitas Brawijaya \\ Email: ittahapsari1@gmail.com
}

Abstract

The dissolution is an act which loses a company's existence and its business continuity. The dissolution application through court is regulated in the 2007 Law Number 40, Article 146 Clause (1) Part C concerning a Limited Company (trans. Indo: Perseroan Terbatas). The dissolution application is a possible option done by shareholders if there is 50\% share balance in the company which cannot be legally decided by Annual Shareholders Meeting. This paper analyzes legal protection of the shareholders while applying the Limited Company dissolution to the court. The method is normative juridical used to analyze the law protection for shareholders in dissolution application (a study on the Verdict Number: 534 K/Pdt/2014) which is related to the Article 146 Clause (1) Part C. The result reveals that the legal protection of shareholders in the process of company's dissolution application is divided into two. Preventive legal protection on PT. DCI's case is an opportunity to issue company's dissolution to save shareholders' assets. Repressive legal protection is applied during the process to solve the dispute among the shareholders.

Pembubaran adalah tindakan yang mengakibatkan perseroan berhenti eksistensinya dan tidak lagi menjalankan bisnisnya. Permohonan pembubaran perseroan Terbatas kepada Pengadilan diatur dalam Pasal 146 ayat (1) hurufc UUPT. Permohonan pembubaran Perseroan Terbataskepada Pengadilan adalah cara yang dapat ditempuh oleh pemegang saham jika terdapat perimbangan kepemilikan saham pada perseroan masing-masing sebesar 50\% dimana Rapat Umum Pemegang Saham (RUPS) 
tidak dapat mengambil keputusan yang sah karena perimbangan kepemilikan saham tersebut. Tujuan penulisan ini untuk menganalisis perlindungan bukum para pemegang saham dalam proses permohonan pembubaran perseroan Terbatas kepada Pengadilan. Metode yang digunakan dalam penulisan ini adalah yuridis normatif, metode penelitian ini digunakan untuk menganalisisperlindungan hukum pemegang saham dalam permohonan pembubaran Perseroan Terbatas (Studi Putusan Nomor: 534 K/Pdt/2014) dikaitkan dengan pasal 146 ayat (1) buruf c UUPT. Hasil penelitian ini bahwa perlindungan hukum para pemegang saham dalam proses permohonan pembubaran Perseroan Terbatas kepada Pengadilan terbagi menjadi dua. Perlindungan hukum preventifpada kasus PT. DCI adalab kesempatan untuk mengajukan pembubaran perseroan guna menyelamatkan aset-asetpemegang saham yang ada pada perseroan. Perlindungan hukum represif pengajuan permohonan pembubaran perseroan kepada Pengadilan untuk menyelesaikan sengketa antara para pemegang saham.

Keywords: the dissolution, limited liability, the law protection, shareholders

\section{Pendahuluan}

Perseroan Terbatas yang selanjutnya disebut perseroan merupakan badan usaha berbadan hukum yang dalam menjalankan kegiatan usahanya dengan tujuan untuk memperoleh keuntungan (profit oriented). Perseroan banyak diminati pelaku usaha karena pertanggung jawabannya bersifat terbatas, perseroan juga memberi kebebasan bagi para pemegang saham untuk mengalihkan atau memperjualbelikan saham yang dimilikinya kepada orang lain, serta keuntungan-keuntungan lainnya. ${ }^{1}$

Saat menjalankan kegiatan usahanya, perseroan tidak selalu berjalan lancar seperti yang diharapkan oleh para pendirinya, seiring berjalannya waktu perseroan pasti mengalami hambatan, baik hambatan internal maupun eksternal yang dapat mengakibatkan kegiatan usahanya tidak dapat dilanjutkan karena sudah tidak lagi memberikan keuntungan, justru menimbulkan banyak kerugian bagi perseroan. ${ }^{2}$ Jika kegiatan usaha yang dilakukan tidak lagi memberikan keuntungan pembubaran menjadi suatu kegiatan yang berakibat pada berhentinya eksistensi perseroan dan tidak menjalankan kegiatan usahanya dalam jangka waktu tertentu. Kemudian, diikuti dengan proses administrasi berupa pemberitahuan, pengumuman dan pemutusan hubungan kerja dengan karyawannya. ${ }^{3}$

Bab X Undang-undang Nomor 40 Tahun 2007 Tentang Perseroan Terbatas (selanjutnya disebut dengan UUPT) mengatur mengenai Pembubaran, Likuidasi, dan Berakhirnya Status Badan Hukum Perseroan. Pengaturan mengenai pembubaran

1 Ahmad Yani dan Gunawan Widjaja, Perseroan Terbatas (Jakarta: PT. Raja Grafindo Persada, 2003), h. 1

2 Azizah, Hukum Perseroan Terbatas (Malang: Intimedia, 2015), h. 67

3 Munir Fuady, Perseroan Terbatas Paradigma Baru (Bandung: Citra Aditya Bakti, 2003), h. 178 
tersebut masih didapati kesulitan dalam penerapannya, salah satunya adalah mengenai cara atau prosedur penyelesaian apabila terjadi keseimbangan komposisi pemilikan saham antara para pemegang saham dengan komposisi masing-masing sebesar 50\% (lima puluh persen). Pada posisi ini, perseroan mengadakan Rapat Umum Pemegang Saham (selanjutnya disebut dengan RUPS) dengan acara rapat pembubaran perseroan tidak akan mendapatkan keputusan yang sah sebagaimana mestinya, karena seimbangnya pemilikan saham para pemegang saham. Dalam hal seimbangnya jumlah pemilikan saham, para pemegang saham yang mengakibatkan tidak terpenuhi keputusan RUPS yang sah, biasanya melakukan pengajuan permohonan pembubaran perseroan melalui Pengadilan Negeri. ${ }^{4}$

Proses pembubaran melalui Pengadilan Negeri sesuai dengan Pasal 146 ayat(1) UUPT yang menyatakan: ${ }^{5}$

Pengadilan negeri dapat membubarkan Perseroan:

a. permohonan kejaksaan berdasarkan alasan Perseroan melanggar kepentingan umum atau Perseroan melakukan perbuatan yang melanggar peraturan perundang-undangan;

b. permohonan pihak yang berkepentingan berdasarkan alasan adanya cacat hukum dalam akta pendirian;

c. permohonan pemegang saham, Direksi, atau Dewan Komisaris berdasarkan alasan Perseroan tidak mungkin untuk dilanjutkan.

Berdasarkan uraian pasal tersebut, dapat disimpulkan bahwa Pengadilan dapat membubarkan perseroan atas permohonan para pihak sebagai berikut:

Kantor Kejaksaan;

1. Pihak yang berkepentingan dalam perseroan;

2. Pemegang Saham, Direksi, atau Komisaris.

3. Pemegang saham merupakan salah satu stake holders dalam suatu perseroan disamping stake holders yang lain, seperti pekerja, kreditor, investor, konsumen, atau pun masyarakat secara keseluruhan. ${ }^{6}$ Para pemegang saham dalam suatu perseroan juga merupakan pihak yang membawa dana ke dalam perseroan, sehingga di samping disebut sebagai stake holders, disebut juga sebagai bag holders (baca: investor) bagi perusahaannya. ${ }^{7}$

Terkait hal-hal yang telah diuraikan di atas, terdapat contoh kasus yang terjadi pada Perseroan Terbatas PT. Damai Colombus International yang berkedudukan

4 Dessy Saida Sry Hadini Simbolon, Pembubaran Perseroan Terbatas Berdasarkan Putusan Hakim (Studi Putusan Mahkamah Agung Republik Indonesia Putusan Nomor: 253 Pk/Pdt/2012), Jurnal Program Magister Kenotariatan Fakultas Hukum Universitas Sumatera Utara, 2012, h. 2

5 Pasal 146 ayat (1) UUPT

6 Tri Budiyono, Hukum Perusahaan (Salatiga: Griya Media, 2011), h. 34

7 Munir Fuady, Perseroan Terbatas Paradigma Baru (Bandung: Citra Aditya Bakti, 2003), h. 1 
di Jakarta (selanjutnya disebut dengan PT. DCI) dimana salah satu pemegang sahamnya mengajukan pembubaran PT. DCI kepada Pengadilan Negeri Jakarta Barat. PT. DCI adalah perseroan yang bidang usahanya merakit kursi mobil dan prosuksi barang-barang dari kulit. PT. DCI memiliki susunan pemegang saham sebagai berikut:

1. Tuan Santoso Widjaya, selaku pemegang/pemilik 5.000 (lima ribu) lembar saham atau sebesar 50\% (lima puluh persen) saham dalam PT. DCI.

2. Tuan Suciento Wongso, selaku pemegang/pemilik 5.000 (lima ribu) lembar saham atau sebesar 50\% (lima puluh persen) saham dalam PT. DCI.

Perimbangan jumlah saham dalam PT. DCI dijadikan dasar untuk mengajukan permohonan pembubaran perseroan kepada Pengadilan oleh pemegang saham Tuan Santoso Widjaya, karena jika diadakan RUPS tidak akan memberikan keputusan yang sah karena jumlah saham masing-masing $50 \%$ karena jika PT. DCI mengadakan RUPS dengan agenda pembubaran perseroan, tidak akan diperoleh suara yang sah karena komposisi saham yang sama. Dasar tidak dapat diadakannya RUPS bagi PT. DCI untuk membubarkan perseroan tercantum dalam Penjelasan Pasal 146 ayat(1) huruf c butir c UUPT, yang menyatakan bahwa:

"dalam perimbangan pemilikan saham dalam Perseroan demikian rupa sehingga RUPS tidak dapat mengambil keputusan yang sah, misalnya 2 (dua) kubu Pemegang Saham memiliki masing-masing 50\% (lima puluh persen)"

Pasal tersebut dijadikan dasar pengajuan pembubaran PT. DCI oleh pemegang saham kepada Pengadilan, yang sesuai dengan isi Pasal 146 ayat(1) huruf c UUPT yang menyatakan bahwa:

"Pengadilan Negeri membubarkan Perseroan atas permohonan Pemegang Saham,

Direksi atau Dewan Komisaris berdasarkan alasan Perseroan tidak mungkin untuk dilanjutkan."

Alasan perseroan tidak mungkin dilanjutkan terdapat dalam penjelasan Pasal 146 ayat (1) huruf c UUPT, yaitu: ${ }^{10}$

1. Perseroan tidak melakukan kegiatan usaha (tidak aktif) selama tiga tahun atau lebih, yang dibuktikan dengan surat pemberitahuan yang disampaikan kepada instansi pajak.

2. Dalam hal Pemegang Saham sudah tidak diketahui domisilinya walaupun telah dipanggil melalui iklan dalam Media Cetak, sehingga tidak dapat diadakan RUPS.

8 Penjelasan Pasal 146 ayat (1) huruf c butir c UUPT

9 Penjelasan Pasal 146 ayat (1) huruf c butir c UUPT

10 Penjelasan Pasal 146 ayat (1) huruf c butir c UUPT 
3. Dalam perimbangan pemilikan saham dalam perseroan, sehingga RUPS tidak dapat mengambil keputusan yang sah, misalnya dua Pemegang Saham memiliki masing-masing 50\% saham, atau

4. Kekayaan perseroan telah berkurang, sehingga dengan kekayaan yang ada perseroan tidak mungkin lagi melanjutkan kegiatan usahanya. Dengan memperhatikan penjelasan tersebut di atas, maka yang menjadi dasar atau alasan-alasan perseroan tidak mungkin untuk dilanjutkan adalah tidak berlaku secara kumulatif (keseluruhan).

Pemegang saham yang mengajukan pembubaran kepada Pengadilan Negeri Jakarta Barat merasa tidak puas dengan putusan pengadilan yang menolak Permohonan, melakukan upaya hukum yaitu kasasi kepada Mahkamah Agung. Dalam hal ini pemegang saham PT. DCI mengajukan permohonan kasasi atas perkara tersebut, sesuai dengan Putusan Nomor: $534 \mathrm{~K} / \mathrm{Pdt} / 2014$.

Hal ini mencerminkan adanya permasalahan dalam putusan hakim, karena dasar pengajuan permohonan pembubaran PT. DCI oleh pemegang saham kepada Pengadilan telah sesuai dengan kententuan isi pasal 146 ayat (1) huruf $\mathrm{c}$ berikut penjelasannya. Pada penjelasan Pasal 146 ayat (1) huruf c butir c juga sudah jelas dinyatakan bahwa jika dalam hal perimbangan pemilikan saham dalam perseroan masing-masing sebesar 50\% sehingga RUPS tidak dapat mengambil keputusan yang sah maka jalan satu-satunya untuk membubarkan perseroan adalah dengan mengajukan permohonan kepada Pengadilan.

Berdasarkan uraian di atas, maka penulis tertarik untuk melakukan penelitian terkait "Perlindungan Hukum Para Pemegang Saham Dalam Proses Permohonan Pembubaran Perseroan Terbatas Kepada Pengadilan" (Studi Putusan Nomor: 534 $\mathrm{K} / \mathrm{Pdt} / 2014)$.

\section{Metode Penelitian}

Metode penelitian yang digunakan dalam penelitian ini adalah yuridis normatif dengan pendekatan kasus (case approach) yang fokus kepada kasus berdasarkan Putusan Nomor: $534 \mathrm{~K} / \mathrm{Pdt} / 2014$ dan pendekatan perundang-undangan (statute aproach) yang fokus pada pengaturan pasal 146 ayat (1) huruf c UUPT dan digunakan untuk menganalisis perlindungan hukum para pemegang saham dalam proses permohonan pembubaran Perseroan Terbatas kepada Pengadilan.

Jenis bahan hukum dalam penelitian ini terdiri atas bahan hukum primer dan bahan hukum sekunder. Bahan hukum primer dalam penelitian ini adalah norma-norma hukum yaitu Pasal 146 ayat (1) huruf c berikut penjelasannya dalam UUPT dan Putusan Mahkamah Agung Nomor: 534 K/Pdt/2014. Sedangkan, 
bahan hukum sekunder yaitu buku teks hukum (legal text book), jurnal hukum, karya tulis hukum yang memuat pandangan ahli hukum dalam bentuk buku maupun yang termuat dalam media masa, media internet; dan bahan hukum lain di luar dari bahan hukum primer. Sumber Bahan Hukum dalam penelitian ini didapatkan dari Perpustakaan Umum Kota Malang, Perpustakaan Pusat Universitas Brawijaya Malang, Pusat Dokumentasi dan Informasi Hukum (PDIH) Fakultas Hukum Universitas Brawijaya Malang, dan Media Internet.

Teknik pengumpulan bahan hukum dilakukan dengan cara penelusuran bahan hukum primer dan sekunder, dilakukan melalui studi kepustakaan (library research) dengan cara menghimpun semua peraturan perundang-undangan dan buku-buku yang berkaitan dengan permasalahan. Selanjutnya untuk peraturan perundang-undangan akan dikaji kaidah hukum dari masing-masing isi pasal yang berkaitan dengan permasalahan, sementara untuk buku akan diambil teori, maupun pernyataan yang terkait dan akhirnya semua bahan hukum tersebut akan disusun secara sistematis agar mempermudah proses analisis.

Teknik analisis bahan hukum yang diperoleh dari penelusuran kepustakaan dan dianalisis menggunakan metode analisis kualitatif. Bahan hukum yang diperoleh selanjutnya dilakukan pembahasan, pemeriksaan, dan pengelompokan ke dalam bagian-bagian tertentu untuk diolah menjadi informasi. Hasil analisis bahan hukum akan diinterpretasikan menggunakan metode interpretasi sebagai berikut: Metode interpretasi sistematis. Metode ini digunakan untuk menganalisis peraturan perundang-undangan terkait permasalahan dalam Putusan Nomor: $534 \mathrm{~K} / \mathrm{Pdt} / 2014$ dengan isi Pasal 146 ayat (1) huruf c berikut penjelasannya terhadap dasar pertimbangan hakim dalam memutuskan permohonan pembubaran Perseroan Terbatas oleh pemegang saham dan perlindungan hukum para pemegang saham dalam permohonan pembubaran Perseroan Terbatas. Selanjutnya, metode interpretasi gramatikal. Metode ini digunakan untuk menganalisis Pasal 146 ayat (1) huruf c UUPT.

\section{Pembahasan}

Perlindungan Hukum Para Pemegang Saham Dalam Proses Permohonan Pembubaran Perseroan Terbatas Kepada Pengadilan

Bab X UUPT tentang Pembubaran, Likuidasi, dan Berakhirnya Status Badan Hukum tidak diberikan definisi yang dimaksud dengan pembubaran dan likuidasi. ${ }^{11}$ Pembubaran dan likuidasi tidak dapat sekaligus dilakukan. Utangutang perseroan harus dilunasi dan tagihan-tagihan harus ditagih, sehingga harta

11 Rudhi Prasetya, Perseroan Terbatas Teori dan Praktik (Jakarta Sinar Grafika, 2014), h. 166 
kekayaan riel dalam bentuk kontan. Harta kekayaan terdiri dari barang-barang tetap ( $f(x$ assets) dan harta kekayaan lainnya harus dijual hingga menjadi uang tunai. ${ }^{12}$ Semua hak-hak harus menjadi bentuk kontan (tunai), harus menjadi liquit (cair), untuk dapat dibagikan kepada pemegang saham sebanding dengan besarnya nilai saham yang dimiliki masing-masing. Kegiatan tersebut tentunya tidak dapat dilakukan seketika, melainkan dibutuhkan tindakan-tindakan "pemberesan" dan diperlukan waktu untuk melakukan pemberesan itu. ${ }^{13}$ Masa tenggang waktu sebelum pembubaran untuk menjalani pemberesan inilah yang dinamakan masa tenggang waktu "likuidasi" perseroan. ${ }^{14}$

Menurut Philipus M. Hadjon, perlindungan hukum adalah sebagai kumpulan peraturan atau kaidah yang akan dapat melindungi suatu hal dari hal lainnya. Berkaitan dengan konsumen, berarti hukum memberikan perlindungan terhadap hak-hak pelanggan dari sesuatu yang mengakibatkan tidak terpenuhinya hak-hak tersebut.

Menurut Hadjon, perlindungan hukum bagi rakyat meliputi dua hal, yaitu: ${ }^{15}$

"(1)Perlindungan bukum preventif adalab bentuk perlindungan bukum dimana kepada rakyat diberi kesempatan untuk mengajukan keberatan atau pendapatnya sebelum suatu keputusan pemerintah mendapat bentukyang definitif, (2) Perlindungan bukum represif adalah bentuk perlindungan hukum dimana lebih ditujukan dalam penyelesaian sengketa."

Secara konseptual, perlindungan hukum yang diberikan bagi rakyat Indonesia merupakan implementasi atas prinsip pengakuan dan perlindungan terhadap harkat dan martabat manusia yang bersumber pada Pancasila dan prinsip negara hukum yang berdasarkan Pancasila. Perlindungan hukum hakikatnya setiap orang berhak mendapatkan perlindungan dari hukum. Hampir seluruh hubungan hukum harus mendapat perlindungan dari hukum.

Perlindungan hukum para pemegang saham dalam proses permohonan pembubaran Perseroan Terbatas kepada Pengadilan, jika dianalisis menggunakan teori perlindungan hukum menurut Philipus M. Hadjon diperoleh hasil sebagai berikut: ${ }^{16}$

12 Rudhi Prasetya, Perseroan Terbatas..., h. 167

13 Rudhi Prasetya, Perseroan Terbatas..., h. 167

14 H.M.N. Purwosutjio, Pengertian Pokok. Hukum Dagang Indonesia (Jakarta: Djambatan, 1979), h. 3

15 Philipus M. Hadjon, Perlindungan Bagi Rakyat di Indonesia (Surabaya: PT. Bina Ilmu, 1987), h. 1-2

16 Philipus M. Hadjon, Perlindungan..., h. 7 


\section{Perlindungan Hukum Preventif}

Perlindungan hukum preventif dalam kasus yang terjadi pada PT. DCI adalah kesempatan untuk mengajukan pembubaran perseroan guna menyelamatkan aset-aset atau harta pemegang saham yang ada pada perseroan. ${ }^{17}$ Pembubaran perseroan juga telah dinyatakan pada aturan Pasal 146 ayat (1) huruf c UUPT yang menyatakan bahwa: "Pengadilan negeri dapat membubarkan Perseroan atas: permohonan pemegang saham, Direksi atau Dewan Komisaris berdasarkan alasan Perseroan tidak mungkin untuk dilanjutkan."

Pada UUPT menjelaskan bahwa perlindungan hukum preventif para pemegang saham. Hak-hak tersebut adalah sebagai berikut: ${ }^{18}$

1. Hak mengajukan gugatan langsung (direct suit)

Pasal 61 ayat (1) UUPT, pemegang saham tanpa menghiraukan berapa persen saham yang dimilikinya berhak untuk mengajukan gugatan terhadap perusahaan ke Pengadilan apabila pemegang saham tersebut mengalami kerugian oleh karena tindakan-tindakan yang tidak adil dan tanpa alasan yang jelas, yang dilakukan oleh Direksi, Dewan Komisaris maupun oleh Rapat Umum Pemegang Saham.

2. Hak mengajukan gugatan derivatif (derivative suit)

Derivative Suit adalah gugatan berdasarkan hak utama (primary right) dari perseroan yang dilakukan oleh pemegang saham atas nama perseroan. ${ }^{19}$ Gugatan derivatif yang dimana justru diwakili oleh pemegang saham untuk menggugat Direksi yang menjadi pihak tergugat. Pada Pasal 97 ayat (6) dan Pasal 114 ayat (6) UUPT memperkenankan pelaksanaan hak untuk mengajukan gugatan derivatif kepada pemegang saham dengan syarat sebagai berikut:

a. Gugatan dilakukan oleh 10\% (sepuluh persen) pemegang saham, dan;

b. Gugatan diajukan hanya kepada Direksi dan/atau Dewan Komisaris yang berkepentingan

3. Hak melakukan pemeriksaan dokumen Perusahaan

Pasal 138 ayat (1) UUPT menyatakan bahwa pemeriksaan terhadap dapat dilakukan dengan tujuan untuk mendapatkan data atau keterangan dalam hal terdapat dugaan bahwa:

17 C. S. T Kansil, Pokok-pokok Pengetahuan Hukum Dagang Indonesia, Jakarta, 2013, h. 78-79

18 Maya Sari, Abdul Rachmad Budiono, Hanif Nur Widhiyanti, Analisa Perlindungan Hukum

Bagi Pemegang Saham Minoritas Dalam Proses Akuisisi Berdasarkan Pasal 126 Undang-

Undang Nomor 40 Tahun 2007, JIPPK, Vol 2, No 2 (2017): Desember 2017 Malang, 2017, h. 115-124

19 Munir Fuady, Hukum Tentang Akuisisi..., h. 174 
a. Perseroan melakukan perbuatan melawan hukum yang merugikan pemegang saham atau pihak ketiga; atau

b. Anggota Direksi atau Dewan Komisaris melakukan perbuatan melawan hukum yang merugikan atau pemegang saham atau pihak ketiga. ${ }^{20}$

Para pemegang saham berhak untuk meminta dilakukan pemeriksaan oleh Pengadilan Negeri setempat dengan mengajukan permohonan secara tertulis, dengan tujuan untuk mendapatkan data dari perseroan, sehubungan dengan adanya dugaan kecurangan-kecurangan atau perbuatan melawan hukum yang dilakukan oleh Direksi, Komisaris atau pemegang saham mayoritas. ${ }^{21}$

4. Hak meminta dilaksanakannya RUPS

Permintaan untuk dilaksanakannya RUPS dapat dilakukan oleh pemegang saham bilamana pemegang saham merasa ada hal-hal yang penting yang perlu diputuskan dalam rapat. Menurut Pasal 79 ayat (2) UUPT yang menyatakan bahwa: ${ }^{22}$

"1 (satu) orang atau lebih pemegang saham yang mewakili 1/10 (satu persepulub) dari seluruh jumlah saham dengan hak suara, berhak meminta penyelenggaraan RUPS.”

Dengan tidak dilakukannya pemanggilan RUPS oleh Direksi atau Dewan Komisaris maka pemegang saham dapat melakukan pemanggilan sendiri sesuai dengan Pasal 80 ayat (1) UUPT yang menyatakan bahwa:

"Pemegang saham minoritas berhak untuk mengajukan permohonan kepada ketua Pengadilan Negeriyang daerah hukumnya meliputi tempat didirikan, agarmemberikan izin kepada pemohon untuk melakukan pemanggilan sendiri." 23

5. Hak meminta perseroan dibubarkan

UUPT memberikan hak kepada pemegang saham untuk dapat mengajukan usulan atau meminta agar dibubarkan. Permintaan pembubaran tersebut dilakukan melalui RUPS. ${ }^{24}$ Dalam Pasal 144 ayat (1) menyatakan bahwa: "Direksi, Dewan Komisaris, dan pemegang saham minoritas yang mewakili paling sedikit 1/10 (satu persepulub) bagian dari selurub sabam dengan hak suara dapat mengajukan usulan agar dibubarkan melalui RUPS."

20 Pasal 138 ayat (1) UUPT

21 Pasal 138 ayat 3 butir a UUPT

22 Pasal 79 ayat 2 UUPT

23 Pasal 80 ayat (1) UUPT

24 Musriansyah, Sihabudin, Perlindungan Hukum Terhadap Pemegang Saham Dalam Penjualan Aset Perseroan Berdasarkan Pasal 102 Ayat (4) Undang-Undang Nomor 40 Tahun 2007 Tentang Perseroan Terbatas, Malang, JIPPK, Vol 2, No 2 (2017): Desember 2017, Malang, 2017 h. $125-131$ 
Pembubaran dapat dilakukan karena pembubaran hanya dapat dilakukan apabila memenuhi syarat yang ada dalam Pasal 87 ayat (1) dan Pasal 89.

Pembubaran juga dapat dilakukan oleh Pengadilan Negeri atas permintaan dari para pemegang saham seperti yang tertulis dalam Pasal 146 ayat (1) huruf $(\mathrm{c})$ UUPT yang menyatakan bahwa:

"Pengadilan Negeri dapat membubarkan ataspermohonan Pemegang Saham, Direksi atau Dewan Komisaris berdasarkan alasan tidak mungkin untuk dilanjutkan" 25

6. Hak untuk memperoleh keterbukaan informasi

UUPT sebagai peraturan yang melindungi pemegang saham mengatur tentang asas keterbukaan yang merupakan dasar dari perlindungan para pemegang saham. Asas keterbukaan dalam UUPT diwujudkan melalui pengaturan dalam pasal-pasal yang mewajibkan untuk mengumumkan kegiatan atau dokumen tertentu suatu melalui beberapa sarana kewajiban pengumuman antara lain pendirian perseroan, perubahan modal dasar, laporan tahunan dan sebagainya. ${ }^{26}$ Seluruh aturan yang terdapat dalam pasal-pasal UUPT mengatur keterbukaan dalam hal pengumuman dilakukan melalui media surat kabar agar publik mengetahui perubahan-perubahan yang terjadi dalam perseroan.

7. Hak untuk menjual saham (appraisal right)

Hak untuk menjual saham (appraisal right) merupakan wujud dari pelaksanaan Pasal 62 UUPT di mana pemegang saham yang tidak setuju dilakukannya akuisisi dapat meminta untuk membeli saham yang dimilikinya. Tetapi hak untuk membeli kembali saham-saham ini dibatasi "maksimum tidak boleh melebihi 10\% (sepuluh persen) dari modal yang ditetapkan." Harga pantas menurut UUPT dapat dikenali dengan menggunakan 3 (tiga) teori sebagai berikut: ${ }^{27}$

a. Teori Nilai Perolehan

Teori nilai perolehan (earnings value) berpedoman pada nilai investasi.

Nilai perolehan ini adalah nilai yang akan dicapai perseroan pada masa yang akan datang (future earnings) setelah dipotong dengan nilai yang diperoleh perusahaan sekarang (present value)

b. Teori Nilai Pasar

Teori nilai pasar (market value) mengajarkan bahwa harga saham dilihat berdasarkan nilai pasar saham yang bersangkutan sebelum diumumkannya

25 Pasal 146 ayat (1) UUPT

26 Tuti Rastuti, Seluk Beluk Perusahaan \& Hukum Perusahaan (Bandung: Refika Aditama, 2015), h. 45

27 Munir Fuady, Hukum Tentang Akuisisi..., h 135 
tersebut.

c. Teori Nilai Aset

Teori nilai aset ini menyatakan bahwa harga dari saham yang akan dibeli dalam hal pemegang saham melaksanakan appraisal rights adalah sebesar harga aset di pasar yang wajar. Appraisal rights membuat harga saham tersebut meningkat seandainya dalam hal tersebut terdapat aset-aset yang untuk sementara tidak aktif atau tidak menghasilkan, padahal aset tersebut lumayan material besarnya.

Menurut dalil dalam al-Quran perlindungan hukum para pemegang saham harus sesuai dengan dalil kemaslahatan umat. Menurut Imam al-Ghazaly bahwa yang dimaksud dengan mashlahah ialah: "Menggapai segala manfaat dan menolak segala mudharat."28

Imam al-Ghazaly menyebutkan bahwa maksud dari perwujudan mahslahah disini bukan berdasarkan kepada keinginan manusia ataupun semata-mata hanya untuk kebaikan atas dasar keinginan mereka. Akan tetapi yang menjadi patokan untuk mewujudkan mashlahah di sini adalah berdasarkan kepada tujuan yang telah digariskan oleh sang Khaliq dalam rangka menciptakan kemaslahatan bagi makhluk-Nya. Dengan demikian, kemashlahan penting digunakan sebagai pedoman dalam penyelesaian sengketa antara para pemegang saham agar terwujud perlindungan hukum para pemegang saham dalam proses pengajuan pembubaran perseroan kepada Pengadilan.

\section{Perlindungan Hukum Represif}

Pada kasus ini, bentuk perlindungan hukum represif dapat dianalisis melalui Putusan Nomor: $534 \mathrm{~K} / \mathrm{Pdt} / 2014$. Dalam penyelesaian sengketa antara para pemegang saham PT. DCI telah ditempuh perbuatan hukum sebagai berikut:

Pemohon yaitu Tuan Santoso Widjaya mengajukan permohonan pembubaran PT. DCI karena pemohon menganggap PT. DCI tidak mungkin dilanjutkan karena hubungan yang tidak harmonis antara pemegang saham. Pengajuan permohonan kepada Pengadilan merupakan perlindungan hukum represif untuk menyelesaikan sengketa antara para pemegang saham pada PT. DCI. Pengajuan permohonan pembubaran PT. DCI didasari fakta-fakta lain sebagai berikut:

Perimbangan kepemilikan saham dalam PT. DCI tidak memungkinkan RUPS PT. DCI dapat mengambil keputusan yang sah, karena masing-masing pemegang saham, yaitu Pemohon dan Termohon I memiliki persentase kepemilikan

28 Abu Hamid Muhammad bin Muhammad bin Muhammad al-Gazhaly, Mustashfa min Ilmi al-Ushul, Madinah Munawwarah, Jilid 2, 1998, h. 481 
saham 50\% . Tuan Suciento Wongso (Termohon I) selaku pemegang 5.000 (lima ribu) lembar saham dengan nominal Rp. 100.000,- (seratus ribu rupiah) atau senilai Rp. 500.000.000,- (lima ratus juta rupiah) yang presentasenya sebesar 50\% (lima puluh persen) dari seluruh total saham PT. DCI. Sedangkan, Tuan Santoso Widjaya (Pemohon) selaku pemegang 5.000 (lima ribu) lembar saham dengan nominal Rp. 100.000,- (seratus ribu rupiah) atau senilai Rp. 500.000.000,- (lima ratus juta rupiah) yang presentasenya sebesar $50 \%$ (lima puluh persen) dari seluruh total saham PT. DCI, dengan demikian total seluruh saham PT. DCI adalah 10.000 (sepuluh ribu) lembar saham. Dasar pengajuan pembubaran perseroan oleh pemegang saham, berdasarkan fakta di atas sesuai dengan penjelasan Pasal 146 ayat (1) huruf c butir c yang menyatakan bahwa: "dalam hal perimbangan pemilikan saham dalam Perseroan demikian rupa sehingga RUPS tidak dapat mengambilkeputusan yang sah, misalnya 2 (dua) kubu pemegang saham memiliki masing-masing 50\% (lima pulub persen) saham."

Ketidakcocokan antara pemegang saham PT. DCI mempengaruhi pengurusan dalam perseroan. Pemegang saham sekaligus Direktur Utama PT. DCI atau Termohon I seringkali mengabaikan kewajiban untuk membayar gaji karyawan dan menolak untuk menandatangani cek-cek dan/atau giro yang diajukan oleh Pemohon untuk kepentingan PT. DCI. Hal ini berakibat sering tertundanya pembayaran gaji kepada karyawan.

Dasar pengajuan pembubaran perseroan oleh pemegang saham, berdasarkan fakta di atas dapat diamati bahwa Termohon I selaku Direktur Utama tidak melaksanakan tugasnya sebagai salah satu Direksi dalam Perseroaan yang seharusnya sesuai dengan Pasal 97 ayat (1) juncto Pasal 92 ayat (1) UUPT yang menyatakan bahwa: "Direksi bertanggungjawab ataspengurusan Perseroan sebagaimana dimaksud salam Pasal 92 ayat (1)"29 juncto "Direksi menjalankan pengurusan Perseroan untuk kepentingan Perseroan dan sesuai dengan maksud dan tujuan Perseroan" 30

Menurut Pemohon I, Termohon I selaku Direktur Utama tidak menjalankan tanggung jawabnya sesuai Pasal 97 ayat (1) juncto Pasal 92 ayat (1) UUPT. Selaku Direksi seharusnya melaksanakan pengurusan perseroan dan tidak lalai dalam pembayaran gaji karyawan yang merupakan kewajiban Direksi.

Kekayaan PT. DCI telah berkurang sedemikian rupa sehingga tidak memungkinkan lagi untuk melanjutkan kegiatan usahanya. Para pemegang saham juga telah menjual aset-asetnya berupa tanah dan bangunan yang berlokasi di Jalan Daan Mogot Gang Damai Nomor 1 yang merupakan lokasi usaha atau kantor PT. DCI, sehingga secara de facto PT. DCI sudah tidak lagi memiliki tempat 29 Pasal 97 ayat (1) UUPT

30 Pasal 92 ayat (1) UUPT 
usaha. Aset tersebut dijual untuk melunasi kewajiban-kewajiban PT. DCI kepada Negara berupa pembayaran tunggakan pajak dan pembayaran hutang PT. DCI kepada Bank. Kekayaan PT. DCI yang tersisa hanya berupa mesin-mesin yang secara akuntansi nilainya hanya sebesar kas dan setara kas di rekening Bank. Dasar pengajuan pembubaran perseroan oleh pemegang saham, berdasarkan fakta di atas telah sesuai dengan penjelasan Pasal 146 ayat (1) huruf c butir d yang menyatakan bahwa: Yang dimaksud dengan "alasan Perseroan tidak mungkin dapat dilanjutkan", antara lain: Kekayaan Perseroan telah berkurang demikian rupa sehingga kekayaan yang ada Perseroan tidak mungkin lagi melanjutkan kegiatan usahanya." 31

Salah satu fakta pengajuan permohonan pembubaran perseroan oleh pemegang saham adalah berkurangnya kekayaan PT. DCI yang berakibat dijualnya aset-aset PT. DCI untuk melunasi kewajiban-kewajiban pembayaran berupa tunggakan pajak dan hutang-hutang PT. DCI kepada Bank. Fakta tersebut telah sesuai dengan penjelasan Pasal 146 ayat (1) huruf c butir d. Apabila PT. DCI tidak mengajukan pembubaran perseroan kepada Pengadilan, dikhawatirkan aset-aset yang tersisa nantinya tidak mencukupi nilainya untuk melunasi kewajiban-kewajiban PT. DCI. Oleh karenanya, Pemohon I yang merupaka pemegang saham mengajukan pembubaran perseroan kepada Pengadilan untuk menyelamatkan aset-aset yang tersisa untuk dapat melunasi kewajiban-kewajiban PT. DCI tersebut.

Perselisihan yang terjadi antara Pemohon dengan Termohon I dalam pengurusan PT. DCI juga berdampak pada hilangnya kepercayaan pelanggan yang selama ini memberikan pekerjaan kepada PT. DCI, sehingga pelanggan tidak lagi melanjutkan kerjasamanya yang berarti sudah tidak ada lagi pemasukan bagi PT. DCI. Sedangkan di sisi lain, PT. DCI masih dibebani dengan beban pembayaran gaji karyawan yang harus terus dibayar sampai ada kejelasan terhadap status hubungan kerjanya dengan PT. DCI.

Dasar pengajuan pembubaran perseroan oleh pemegang saham, berdasarkan fakta di atas telah sesuai dengan penjelasan Pasal 146 ayat (1) huruf c butir d yang menyatakan bahwa:

Yang dimaksud dengan "alasan Perseroan tidak mungkin dapat dilanjutkan", antara

lain: Kekayaan Perseroan telah berkurang demikian rupa sehingga kekayaan yang ada Perseroan tidak mungkin lagi melanjutkan kegiatan usahanya." 32

Fakta tersebut dapat juga dijadikan sebagai salah satu alasan pengajuan permohonan pembubaran perseroan karena dinilai merugikan PT. DCI apabila tidak segera dibubarkan. Apabila PT. DCI tidak segera dibubarkan maka akan

31 Pasal 146 ayat (1) huruf c butir d

32 Pasal 146 ayat (1) huruf c butir d 
terus dibebani dengan pembayaran gaji karyawan dan dikhawatirkan adanya penyalahgunaan aset-aset PT. DCI yang masih tersisa, sehingga dapat merugikan pemegang saham dan para pihak yang berkepentingan terhadap PT. DCI.

Adapun fakta-fakta dianggap sebagai perlindungan hukum secara represif para pemegang saham dan seluruh fakta-fakta tersebut telah sesuai dengan ketentuan Pasal 146 ayat (1) hurf c UUPT, merupakan fakta-fakta untuk mengajukan permohonan pembubaran PT. DCI kepada Pengadilan.

\section{Analisis Putusan Nomor: 534 K/Pdt/2014 Berdasarkan Keadilan}

Dalam hukum bisnis, khususnya perseroan PT. DCI, kebebasan yang sama sebesar-besarnya termuat dalam kebebasan menjadi diri sendiri (person) dan hak untuk mempertahan milik pribadi.

Pertama, kebebasan menjadi diri sendiri (person) terwujud dalam kasus yang terjadi pada PT. DCI, salah satu pemegang saham yang juga merupakan Pemohon yaitu Tuan Santoso Widjaya telah mendapatkan kebebasan yang sebesar-besarnya sebagai prioritas untuk mengajukan permohonan pembubaran PT. DCI kepada Pengadilan Negeri Jakarta Barat sesuai tempat kedudukan PT. DCI. Pengajuan permohonan dilakukan oleh salah satu pemegang saham karena tidak memungkinkannya pengambilan suara yang sah dari RUPS akibat komposisi saham yang berimbang, antara Pemohon dan Termohon masing-masing 50\% (lima puluh persen). Pemohon atau Tuan Santoso Widjaya mempunyai kebebasan sebagai diri sendiri yaitu sebagai salah satu pemegang saham yang berhak mengajukan permohonan PT. DCI kepada Pengadilan sebagai jalan satu-satunya jika tidak tercapainya suara yang sah dalam RUPS. Pada prinsip selanjutnya, yaitu hak untuk mempertahankan milik pribadi. Pemohon mengajukan permohonan pembubaran PT. DCI kepada Pengadilan sebagai upaya untuk mempertahankan milik pribadi berupa saham yang ada pada PT. DCI, melakukan permohonan pembubaran kepada Pengadilan merupakan salah satu upaya untuk mempertahankan milik pribadi (saham). Prinsip pertama terkait kebebasan yang sama sebesar-besarnya telah tercapai sebagai salah satu wujud keadilan pemegang saham.

Prinsip ini juga dapat digunakan untuk menganalisis dasar pertimbangan hakim dalam memutuskan permohonan pembubaran perseroan Terbatas oleh pemegang saham. Prinsip yang paling relevan digunakan oleh Hakim dalam memutuskan permohonan pembubaran perseroan yaitu prinsip kebebasan dalam berbicara dan prinsip kebebasan dalam berkeyakinan. Hakim dalam putusannya berkeyakinan bahwa alasan Pemohon untuk membubarkan telah sesuai dengan Pasal 146 ayat (1) hurufc UUPT yang menyatakan bahwa: "Pengadilan negeri dapat 
membubarkan Perseroan atas permohonan pemegang saham, Direksi, atau Dewan Komisaris berdasarkan alasan Perseroan tidak mungkin untuk dilanjutkan."

Menurut Pemohon, dasar permohonan pembubaran telah sesuai dengan Pasal 146 ayat (1) huruf c UUPT, namun dalam dasar pertimbangan Hakim, sebelum mengajukan permohonan pembubaran perseroan oleh Pemohon, hendaknya memperhatikan pemegang saham yang lain meskipun terdapat perimbangan kepemilikan saham sebesar masing-masing 50\% (lima puluh persen) antara Pemohon dan Termohon. Hal ini tentu tidak mencerminkan keadilan bagi pemegang saham lain yaitu Termohon II yang mengakibatkan Hakim menolak permohonan kasasi Pemohon.

Kedua, prinsip perbedaan. Prinsip perbedaan (the differenceprinciple) mengandung arti bahwa perbedaan sosial dan ekonomi harus diukur agar memberikan manfaat yang paling besar bagi mereka yang paling kurang beruntung. Istilah perbedaan sosial ekonomi menunjuk pada ketidaksamaan dalam prospek seseorang untuk mendapatkan unsur pokok kesejahteraan, pendapatan, dan wewenang. Sedangkan istilah yang paling kurang beruntung menunjuk pada mereka yang paling kurang mempunyai peluang atau kesempatan, dan wewenang. ${ }^{33}$

Pada kasus PT. DCI sesuai Putusan Nomor: $534 \mathrm{~K} / \mathrm{Pdt} / 2014$, prinsip perbedaan sedikit berbeda karena dalam PT. DCI para pihak yang berperkara masing-masing adalah pemegang saham. Prinsip perbedaan tidak dapat dilihat secara langsung berdasarkan status para pihak saja, namun dalam dasar pertimbangan hakim dapat ditarik kesimpulan bahwa walaupun status para pihak masing-masing adalah sama yaitu pemegang saham, yang dapat membedakan adalah Pemohon yang mengajukan permohonan pembubaran menjadi pihak yang bertanggungjawab atas permohonannya dan pihak Termohon II menjadi pihak "yang paling kurang beruntung" karena dalam kasus PT. DCI Termohon II tidak terwakili dalam persidangan sedangkan Pemohon yang seharusnya menjadi pihak yang diuntungkan, tidak memperhatikan dasar permohonannya dengan baik. Sehingga, dasar pertimbangan hakim kembali mencerminkan keadilan untuk pemegang saham yang lain dalam hal ini Termohon II untuk menolak permohonan pembubaran oleh Pemohon karena dapat menimbulkan ketidakadilan bagi Termohon II jika PT. DCI dibubarkan sedangkan Termohon II tidak terwakili dalam Persidangan.

Ketiga, prinsip persamaan yang adil atas kesempatan. Prinsip persamaan yang adil atas kesempatan (the principle of fair equality of opportunity) atau mengandung arti bahwa ketidaksamaan sosial ekonomi harus diatur sedemikian rupa sehingga membuka jembatan dan kedudukan sosial bagi semua yang ada di bawah kondisi

33 Pasal 146 ayat (1) huruf c butir d 
persamaan kesempatan. Orang-orang dengan keterampilan, kompetensi, dan motivasi yang sama, dapat menikmati kesempatan yang sama pula. ${ }^{34}$

Prinsip ini tercermin pada pengaturan Pasal 146 ayat (1) huruf c UUPT yang menyatakan bahwa: "Permohonan pemegang saham, Direksi, atau Dewan Komisaris berdasarkan alasan Perseroan tidak mungkin untuk dilanjutkan."

Pasal ini dijadikan dasar oleh Pemohon untuk mengajukan permohonan pembubaran perseroan kepada Pengadilan. Pengaturan pada pasal tersebut memang mengandung prinsip persamaan yang adil atas kesempatan khususnya bagi Pemohon. Dasar pertimbangan hakim juga mencerminkan prinsip persamaan yang adil atas kesempatan, karena hakim berpendapat bahwa meskipun dasar permohonan pembubaran yang diajukan oleh Pemohon telah sesuai dengan Pasal 146 ayat (1) huruf c UUPT, namun harus juga memperhatikan persamaan yang adil atas kesempatan untuk pemegang saham yang lain atau Termohon II, atas dasar inilah hakim menolak permohonan Pemohon karena Termohon II tidak terwakili dalam Persidangan.

Pada permohonan pembubaran PT. DCI sesuai dengan Putusan Nomor: 534 K/Pdt/2014 setelah dianalisis menggunakan teori keadilan John Rawls diketahui bahwa putusan tersebut telah mencerminkan keadilan.

Pada prinsipnya, keadilan menurut John Rawls terpenuhi apabila memenuhi 2 (dua) dari 3 (tiga) prinsip yang dikemukakan. ${ }^{35}$ Prinsip pertama yang diprioritaskan yaitu kebebasan yang sama sebesar-besarnya telah terpenuhi dibuktikan dengan dasar pertimbangan hakim yang memihak kepada Termohon II yang tidak terwakili dalam persidangan permohonan pembubaran. Selanjutnya, prinsip kedua yaitu berlaku lebih dahulu dari pada prinsip perbedaan. Prinsip persamaan yang adil atas kesempatan juga telah terpenuhi dibuktikan dengan dasar pertimbangan hakim yang tidak hanya melihat persamaan yang adil bagi Pemohon, tetapi juga persamaan yang adil bagi Termohon II yang tidak terwakili di persidangan permohonan pembubaran perseroan.

Putusan Nomor: $534 \mathrm{~K} / \mathrm{Pdt} / 2014$ telah mencerminkan keadilan menurut teori keadilan oleh John Rawls. Terlepas bahwa Pemohon sudah benar menjadikan Pasal 146 ayat (1) hurufc UUPT sebagai dasar permohonan pembubaran perseroan, tetapi hak pemegang saham yang lain atau Termohon II juga harus diperhatikan oleh hakim agar terwujud keadilan bagi para pihak yang berperkara.

Selanjutnya, keadilan para pemegang saham dalam Putusan Nomor: 534 K/Pdt/2014 dapat dianalisis menggunakan teori keadilan Hans Kelsen. Keadilan

34 Munir Fuady, Hukum Tentang Akuisisi..., h. 135

35 Damanhuri Fattah, Teori Keadilan Menurut John Rawls, Jurnal TAPIs, Vol. 9 No. 2 Juli-Desember 2013, Universitas Raden Intan, Lampung, 2013, h. 13 
para pemegang saham pada Putusan Nomor: $534 \mathrm{~K} / \mathrm{Pdt} / 2014$ dapat dianalisis menggunakan teori keadilan oleh Hans Kelsen dengan prinsip-prinsip sebagai berikut: ${ }^{36}$

\section{Keadilan dan perdamaian}

Kasus yang terjadi pada PT. DCI sesuai dengan Putusan Nomor: 534 $\mathrm{K} / \mathrm{Pdt} / 2014$ dianalisis menggunakan prinsip keadilan dan perdamaian adalah sebagai berikut:

Keadilan dirasionalkan melalui pengetahuan yang dapat berwujud kepentingankepentingan yang pada akhirnya menimbulkan suatu konflik kepentingan. ${ }^{37} \mathrm{Jika}$ dikaitkan dengan kasus yang terjadi pada PT. DCI kepentingan-kepentingan para pemegang saham dapat dilihat pada fakta-fakta dalam Putusan Nomor: $534 \mathrm{~K} /$ Pdt/2014 yaitu sebagai berikut:

a. Pemohon meyakini bahwa PT. DCI mengalami penurunan dalam pendapatan;

b. Pemohon berupaya untuk membubarkan perseroan guna menyelamatkan sisasisa aset pada PT. DCI, namun terkendala perimbangan komposisi saham yang masing-masing $50 \%$;

c. Termohon selaku Direktur Utama mengabaikan kewajiban dalam membayar gaji karyawan dengan menolak menanda-tangani cek-cek dan/atau giro yang diajukan oleh Pemohon karena untuk mengeluarkan uang PT. DCI dan rekening bank, setiap cek dan/atau giro yang dikeluarkan harus ditandatangani oleh kedua pihak.

Kepentingan-kepentingan di atas berakibat konflik yang terjadi antara para pemegang saham karena pemohon menggangap PT. DCI tidak mungkin dilanjutkan karena hubungan yang tidak harmonis antara para pemegang saham. Oleh karena itu, pemohon mengajukan pembubaran perseroan kepada Pengadilan guna mengakhiri konflik kepentingan para pemegang saham. Teori keadilan dan perdamaian dengan penyelesaian atas konflik kepentingan dapat dicapai melalui suatu tatanan yang memuaskan salah satu kepentingan dengan mengorbankan kepentingan yang lain atau dengan berusaha mencapai suatu kompromi menuju suatu perdamaian bagi semua kepentingan. Dengan prinsip ini dapat dianalisis bahwa suatu keadilan dan perdamaian dalam kasus PT. DCI sesuai dengan Putusan Nomor: $534 \mathrm{~K} / \mathrm{Pdt} / 2014$ dapat dicapai dengan mengorbankan kepentingan lain dengan berusaha mencapai suatu kompromi untuk perdamaian. Maka prinsip keadilan dan perdamaian dalam kasus yang ternyata dalam Putusan Nomor: 534

36 Hans Kelsen, General Theory of Law and State, diterjemahkan oleh Rasisul Muttaqien (Bandung: Nusa Media, 2011), h. 232

37 Hans Kelsen, General Theory of Law,... h. 234 
K/Pdt/2014 tersebut sudah tercapai dibuktikan dengan ditolaknya permohonan pembubaran perseroan oleh Pemohon, dalam kata lain Pemohon dalam hal ini telah mengorbankan kepentingannya untuk membubarkan perseroan.

\section{Keadilan dan legalitas}

Kasus yang terjadi berdasarkan Putusan Nomor: $534 \mathrm{~K} / \mathrm{Pdt} / 2014$ peraturan umum yang digunakan khusus mengenai pembubaran perseroan berdasarkan penetapan Pengadilan. Adapun peraturan umum yang digunakan dalam proses pembubaran perseroan berdasarkan penetapan Pengadilan yaitu Pasal 142 ayat (1) huruf c menyatakan bahwa: "Pembubaran Perseroan terjadi berdasarkan penetapan Pengadilan."

Pada kasus yang terjadi pada PT. DCI yang berkedudukan di Jakarta, Pemohon sudah menerapkan aturan Pasal 142 ayat (1) hurufc dengan mengajukan permohonan pembubaran perseroan kepada Pengadilan Jakarta Barat sebagai awal dari proses pembubaran perseroan yang terjadi berdasarkan penetapan Pengadilan.

Selanjutnya, peraturan umum yang digunakan dalam proses pembubaran perseroan berdasarkan penetapan Pengadilan yaitu Pasal 146 ayat (1) huruf c UUPT yang menyatakan bahwa: "Pengadilan Negeri dapat membubarkan Perseroan atas permohonan pemegang saham, Direksi atau Dewan Komisaris berdasarkan alasan Perseroan tidak mungkin dilanjutkan."

Jika Pasal 146 ayat (1) huruf c UUPT dikaitkan dengan kasus PT. DCI, peraturan tersebut sudah diterapkan dalam Putusan Nomor: $534 \mathrm{~K} / \mathrm{Pdt} / 2014$. Adapun dalam dasar permohonan tersebut juga didasari fakta-fakta yang telah dijelaskan dalam Putusan tersebut, antara lain adalah perimbangan kepemilikan saham dalam PT. DCI yang tidak memungkinkan RUPS mengambil keputusan yang sah, karena masing-masing pemegang saham memiliki presentase kepemilikan saham 50\% (lima puluh persen); ketidakcocokan antara pemegang saham PT. DCI mempengaruhi pengurusan PT. DCI; kekayaan PT. DCI telah berkurang sedemikian rupa sehingga tidak memungkinkan lagi untuk melanjutkan usahanya; dan perselisihan yang sering terjadi antara pemegang saham dalam pengurusan PT. DCI yang berdampak pada hilangnya kepercayaan pelanggan yang selama ini memberikan order kepada PT. DCI, sehingga pelanggan tidak lagi melanjutkan kerjasamanya, yang berarti sudah tidak ada lagi pemaksukan bagi perseroan.

Dari analisis menggunakan teori keadilan oleh Hans Kelsen, dapat disimpulkan bahwa Putusan Nomor: 534 K/Pdt/2014 telah memenuhi keadilan 
para pemegang sahamnya. Hal ini dibuktikan dengan terpenuhinya 2 (dua) prinsip di atas yaitu prinsip perdamaian dan legalitas. Prinsip perdamaian dibuktikan dengan ditolaknya permohonan pembubaran perseroan oleh Pemohon, dalam kata lain Pemohon dalam hal ini telah mengorbankan kepentingannya untuk membubarkan perseroan. Sedangkan prinsip legalitas dibuktikan dengan telah diterapkannya peraturan Pasal 142 ayat (1) huruf c UUPT dan Pasal 146 ayat (1) huruf c UUPT oleh Majelis Hakim dalam memutuskan permohonan pembubaran perseroan kepada Pengadilan.

\section{Simpulan}

Berdasarkan hasil pembahasan di atas, penulis menarik beberapa kesimpulan bahwa perlindungan hukum preventif dalam kasus yang terjadi pada PT.DCI adalah kesempatan untuk mengajukan pembubaran perseroan guna menyelamatkan asetaset atau harta pemegang saham yang ada pada perseroan. Pembubaran perseroan juga telah dinyatakan pada aturan Pasal 146 ayat (1) hurufc UUPT. Pada UUPT menjelaskan bahwa perlindungan hukum preventif para pemegang saham. Terdapat 7 (tujuh) hak yang dimiliki para pemegang saham, hak-hak tersebut adalah sebagai berikut: Hak mengajukan gugatan langsung (direct suit); Hak mengajukan gugatan derivatif (derivative suit); Hak melakukan pemerikasaan dokumen perusahaan; Hak meminta dilaksanakannya RUPS; Hak meminta Perseroan dibubarkan; Hak untuk memperoleh keterbukaan informasi; dan Hak untuk menjual saham (appraisal right). Bentuk perlindungan hukum represif lebih ditujukan dalam penyelesaian sengketa. Pada kasus ini, bentuk perlindungan hukum represif dapat dianalisis melalui Putusan Nomor: 534 K/Pdt/2014. Dalam penyelesaian sengketa antara para pemegang saham pada PT. DCI telah ditempuh perbuatan hukum yaitu Tuan Santoso Widjaya mengajukan permohonan pembubaran PT. DCI karena pemohon menganggap PT. DCI tidak mungkin dilanjutkan karena hubungan yang tidak harmonis antara pemegang saham. Pengajuan permohonan kepada Pengadilan merupakan perlindungan hukum represif untuk menyelesaikan sengketa antara para pemegang saham pada PT. DCI.

Prinsip keadilan dan perdamaian dalam kasus tersebut sudah tercapai dibuktikan dengan ditolaknya permohonan pembubaran perseroan oleh Pemohon, dalam kata lain Pemohon dalam hal ini telah mengorbankan kepentingannya untuk membubarkan perseroan. Keadilan dan legalitas, adapun peraturan umum yang digunakan dalam proses pembubaran perseroan berdasarkan penetapan Pengadilan yaitu Pasal 142 ayat (1) huruf c dan Pasal 146 ayat (1) huruf c UUPT sehingga, dapat disimpulkan bahwa Putusan Nomor: 534 K/Pdt/2014 telah 
memenuhi keadilan para pemegang sahamnya. Prinsip perdamaian dibuktikan dengan ditolaknya permohonan pembubaran perseroan oleh Pemohon, Pemohon telah mengorbankan kepentingannya untuk membubarkan perseroan. Sedangkan prinsip legalitas dibuktikan dengan telah diterapkannya peraturan Pasal 142 ayat (1) huruf c UUPT dan Pasal 146 ayat (1) huruf c UUPT oleh Majelis Hakim.

\section{Daftar Pustaka}

\section{Buku}

C. S. T Kansil, Pokok-pokok Pengetahuan Hukum Dagang Indonesia. Jakarta, 2013.

Munir Fuady. Hukum Tentang Akuisisi, Take Over, dan LBO. Bandung: PT. Citra Aditya Bakti, 2014.

Munir Fuady. Perseroan Terbatas Paradigma Baru. Bandung: Citra Aditya Bakti, 2003.

Philipus M. Hadjon. Perlindungan Bagi Rakyat di Indonesia. Surabaya: PT. Bina Ilmu, 1987.

Rudhi Prasetya. Perseroan Terbatas Teori dan Praktik. Jakarta: Sinar Grafika, 2014.

Tri Budiyono. Hukum Perusahaan. Salatiga: Griya Media, 2011.

Tuti Rastuti. Seluk Beluk Perusahaan \& Hukum Perusahaan. Bandung: Refika Aditama, 2015.

\section{Artikel}

Dessy Saida Sry Hadini Simbolon. Pembubaran Perseroan Terbatas Berdasarkan

Putusan Hakim (Studi Putusan Mahkamah Agung Republik Indonesia

Putusan Nomor: 253 Pk/Pdt/2012). Jurnal Program Magister Kenotariatan

Fakultas Hukum Universitas Sumatera Utara, 2012.

Damanhuri Fattah. Teori Keadilan Menurut John Rawls. Jurnal TAPIs Vol. 9 No. 2 Juli-Desember 2013, Universitas Raden Intan, Lampung, 2013.

Maya Sari, Abdul Rachmad Budiono, Hanif Nur Widhiyanti. Analisa Perlindungan Hukum Bagi Pemegang Saham Minoritas Dalam Proses Akuisisi Berdasarkan Pasal 126 Undang-Undang Nomor 40 Tahun 2007. JIPPK Vol 2, No 2 (2017): Desember 2017 Malang, 2017. 
Musriansyah, Sihabudin. Perlindungan Hukum Terhadap Pemegang Saham Dalam Penjualan Aset Perseroan Berdasarkan Pasal 102 Ayat (4) Undang-Undang Nomor 40 Tahun 2007 Tentang Perseroan Terbatas. JIPPK, Vol 2, No 2 (2017): Desember 2017. Malang, 2017.

\section{Peraturan Perundang-undangan}

Undang-undang Nomor 40 Tahun 2007 Tentang Perseroan Terbatas.

Putusan Mahkamah Agung Nomor: 534 K/Pdt/2014 